\title{
PENERAPAN MODEL PEMBELAJARAN LEARNING CYCLE 7E DALAM PEMBELAJARAN IPA TERPADU TERHADAP KETERAMPILAN PROSES SAINS SISWA
}

\author{
Oleh : Nurhaningtyas Agustin* \\ nurhaning@ymail.com
}

\begin{abstract}
This research intent to describe performed learning, skill step-up processes science, and student response by use of learning model $7 E$ in intregated sciences class VIII SMP. This research constitute True Experiment Design. This observational population is all class VIII SMPN 2 Krian Sidoarjo school years 2013 / 2014 ones consisting of 8 classes. Sample that is utilized in this research is class VIII-E as class of experiment and class VIII-F as class of control. Data on observational it is data as yielding as pre-test and post-test skill processes science and studying result, skill observation data processes science and student response questionnaire. Sample gets normal distribution and homogeneous. Result arithmeticing to point out science process skill chastened student with learning model $7 E$ tall increasing happening signifikan's one as big as 0,73 but was reached klasikal's ala thoroughness. Meanwhile studying result happens step-up 0,74 and were reached by presentase thoroughness $97 \%$. It points out that learning model 7E in integrated sciences theme Biomassa's energy can increase prose's skill science and student studying result. Learning model $7 E$ getting positive response of student.
\end{abstract}

Keyword: Learning 7E, Integrated Sciences, skill processes science.

* Nurhaningtyas Agustin adalah Dosen Prodi PGMI Sekolah Tinggi Ilmu Tarbiyah Makhdum Ibrahim

\section{Pendahuluan}

Menurut UU Nomor 20 Tahun 2003 Pasal 1 Ayat (19), kurikulum merupakan seperangkat rencana dan pengaturan mengenai tujuan, isi dan bahan pelajaran serta cara yang digunakan sebagai penyelenggaaraan kegiatan pembelajaran untuk mencapai tujuan pembelajaran tertentu. Kurikulum Tingkat Satuan Pendidikan (KTSP) 2006 mengharuskan Ilmu Pengetahuan Alam (IPA) diajarkan secara terpadu dan utuh. Hal senada juga di ungkapkan oleh Badan Standar Nasional Pendidikan (BSNP). Pembelajaran terpadu dalam IPA dapat dikemas dengan tema atau topik tentang suatu wacana yang dibahas dari berbagai sudut pandang atau disiplin ilmu yang mudah dipahami dan dikenal peserta didik.

Pada faktanya, masih banyak sekolah yang belum mengajarkan pembelajaran IPA Terpadu. Menurut hasil observasi di SMP Negeri 2 Krian Sidoarjo, pembelajaran IPA di sekolah tersebut belum diajarkan secara terpadu. Salah satu penyebabnya, guru IPA di sekolah tersebut memiliki keterampilan pada bidang IPA secara terpisah. 
Ilmu Pengetahuan Alam (IPA) berkaitan dengan cara mencari tahu tentang alam secara sistematis, penguasaan kumpulan pengetahuan yang berupa fakta-fakta, konsep-konsep, prinsip-prinsip dan juga merupakan suatu proses penemuan sehingga sangat penting untuk dipelajari (Depdiknas, 2006:5). Pada kenyataannya, masih banyak siswa yang menganggap IPA sebagai mata pelajaran yang sulit. Hal ini dibuktikan dengan hasil belajar yang diperoleh siswa masih banyak yang belum mencapai Kriteria Ketuntasan Minimal (KKM) yang telah ditetapkan di sekolah. Selain itu juga dapat diketahui melalui penyebaran angket pra-penelitian dengan mengambil sampel 100 siswa yang terdiri dari kelas VII, VIII dan IX kepada siswa di SMP Negeri 2 Krian Sidoarjo, diperoleh data bahwa siswa menganggap IPA adalah pelajaran yang sulit (81\%). Alasannya karena mata pelajaran IPA dianggap memiliki banyak hafalan (18\%), serta memiliki banyak hitungan (44\%), dan cara menerangkan guru yang kurang menarik (38\%).

Dari uraian tersebut dapat disimpulkan bahwa hal penting dalam suatu pembelajaran terutama pembelajaran IPA adalah proses pembelajaran. Dalam pembelajaran IPA proses lebih diutamakan dari pada hasil, hal ini akan menunjukkan bahwa proses akan menjadi ukuran terhadap keberhasilan dalam pencapaian tujuan pembelajaran karena dengan keterampilan prose sains siswa mampu mengkontruksi pengetahuannya sehingga lebih dapat memahami apa yang dipelajari dan merupakan modal utama yang menunjang terhadap penguasaan konsep IPA. Melalui pembelajaran IPA Terpadu peserta didik diharapkan akan lebih termotivasi dalam belajar karena mereka merasa bahwa pembelajaran itu bermakna baginya bila mereka berhasil menerapkan apa yang telah dipelajari. Pembelajaran IPA Terpadu dapat mempermudah dan memotivasi peserta didik untuk mengenal, menerima, menyerap, dan memahami keterkaitan atau hubungan antara konsep pengetahuan yang telah dipadukan dalam suatu tema (Depdiknas, 2006: 9).

Dalam menentukan tema, perlu memperhatikan beberapa hal, yaitu: relevansi tema dengan kompetensi dasar yang dipadukan, tema yang dipilih merupakan isu-isu yang aktual, menarik, dan kontekstual (Depdiknas, 2006: 19). Peneliti memilih tema Energi Biomassa dengan memadukan beberapa Standar Kompetensi (SK) dan Kompetensi Dasar (KD). Tema tersebut dipilih karena merupakan isu aktual yang sedang dialami oleh negara dan dunia sebagai alternatif pengganti kelangkaan energi di dunia untuk masa mendatang.

Dalam pembelajan IPA banyak menemui berbagai kendala seperti siswa kurang termotivasi untuk belajar. Sehingga siswa cepat merasa jenuh dan bosan, kurangnya kesempatan siswa untuk terlibat aktif dan membangun pengetahuannya yang menyebabkan proses belajar mengajar mengajar cenderung pasif dan membosankan yang pada akhirnya akan mempengaruhi hasil belajar siswa. Tingkat keberhasilan belajar mengajar dipengaruhi beberapa faktor salah satunya adalah model pembelajaran yang digunakan oleh guru dalam kegiatan belajar mengajar. Model pembelajaran merupakan salah satu komponen yang penting dan sangat menentukan keberhasilan proses belajar mengajar. Pemilihan model pembelajaran sangatlah penting guna mencapai tujuan pembelajaran. Pembelajaran yang dapat melatihkan keterampilan proses sains pembelajaran dengan pendekatan konstruktivis.

Melalui pembelajaran konstruktivisme siswa belajar secara aktif dan dapat mengaitkan informasi yang baru dengan skema yang telah dimiliki sebelumnya. Diharapkan melalui pembelajaran kontruktivis, pengetahuan yang dimiliki siswa sangat bermakna, relevan dan memberikan kesempatan bagi siswa bagaimana cara siswa bertindak serta berfikir. Salah satu 
model pembelajaran konstruktivis yang membuat siswa secara aktif membangun sendiri pengetahuan dan terpusat pada siswa (student-centered) adalah model Learning Cycle. Model Learning Cycle adalah model pembelajaran konstruktivis (Carin, 1993: 87), yaitu siswa belajar secara aktif, informasi yang baru dikaitkan dengan skema yang telah dimiliki siswa. Berdasarkan uraian diatas tujuan dalam penelitian ini adalah mendeskripsikan keterlaksanaan pembelajaran, mendeskripsikan keterampilan proses sains siswa, ketuntasanhasil belajar siswa, dan respon siswa terhadap kegiatan belajar mengajar dengan menerapkan model pembelajaran $7 E$ dalam IPA Terpadu tema Energi Biomassadi SMP Negeri 2 Krian Sidoarjo.

\section{Metode}

Penelitian ini merupakan penelitian True eksperiment Design dengan menggunakan rancangan Control Group Pre Test Post Test Design. Penelitian dilakukan di SMPN 2 Krian pada tanggal 4 November-14 November 2013. Populasi yang digunakan penelitian adalah seluruh siswa kelas VIII SMP Negeri 2 Krian Sidoarjo dengan jumlah 288 siswa. Subjek yang digunakan dalam penelitian adalah kelas VIII-E sebagai kelas eksperimen dan kelas VIII-F sebagai kelas kontrol dengan jumlah siswa masing-masing kelas 36 siswa.

Data pada penelitian ini adalah data berupa hasil pre test dan post test keterampilan proses sains dan hasil belajar, data observasi keterampilan proses sains, lembar penilaian afektif dan psikomotor siswa, serta angket respon siswa. Teknik analisis data yang digunakan adalah analisis deskriptif berupa uji Gain Score.

\section{Hasil dan Pembahasan}

\section{Analisis keterlaksanaan pembelajaran}

Keterlaksanaan pembelajaran diamati oleh dua pengamat, satu pengamat dari guru bidang studi IPA di SMP Negeri 2 Krian Sidoarjo dan satu pengamat dari mahasiswa sains. Perhitungan skor rata-rata keterlaksanaan pembelajaran dan kriteria dapat dilihat pada Tabel 4.1.

Tabel 4.1 Skor Rata-Rata Keterlaksanaan Pembelajaran

\begin{tabular}{|c|l|c|c|}
\hline $\begin{array}{l}\text { N } \\
\mathbf{0}\end{array}$ & Aspek yang diamati & Penilaian & Kategori \\
\hline 1 & Persiapan & 4 & Sangat baik \\
\hline 2 & $\begin{array}{l}\text { Fase dalam model pembelajaran Learning } \\
\text { Cycle 7E }\end{array}$ & 3,5 & Sangat baik \\
\hline 3 & Pengelolaan waktu & 3,7 & Sangat baik \\
\hline 4 & Suasana kelas & 3,3 & Baik \\
\hline \multicolumn{1}{|c|}{ Rata-rata } & 3,6 & Sangat baik \\
\hline
\end{tabular}

Berdasarkan Tabel 4.1 diketahui bahwa keterlaksanaan pembelajaran yang dilakukan oleh peneliti pada kelas eksperimen (VIII-E) dengan menggunakan model pembelajaran $7 E$ dalam IPA Terpadu tema Energi Biomassa dapat dikatakan terlaksana semua. Adapun skor rata-rata yang paling rendah adalah pada tahap suasana kelas dan skor rata-rata yang paling tinggi adalah pada tahap persiapan. Secara keseluruhan, skor keterlaksanaan sebesar 3,60 termasuk dalam kategori sangat baik dengan tingkat reliabilitas 0,86 . 


\section{Analisis Keterampilan Proses Sains}

Instrumen keterampilan proses sains siswa berupa lembar non tes dan tes. Lembar non tes berupa lembar pengamatan keterampilan proses sains dan lembar tes berupa penilaian keterampilan proses sains. Pada lembar pengamatan keterampilan proses sains, keterampilan proses yang diukur meliputi keterampilan mengamati dan keterampilan mengkomunikasikan. Hasil pengamatan keterampilan proses sains disajikan pada Tabel 4.2.

Tabel 4.2

Rata-Rata Pengamatan Keterampilan Proses Sains Kelas Eksperimen dan Kelas

Kontrol

\begin{tabular}{|l|c|c|}
\hline \multirow{2}{*}{\multicolumn{1}{|c|}{ Kelas }} & \multicolumn{2}{c|}{ Keterampilan Proses Sains } \\
\cline { 2 - 3 } & Mengamati & Mengkomunikasikan \\
\hline Kelas & & \\
Eksperimen & 52 & 64 \\
\hline Kelas Kontrol & 50 & 52 \\
\hline
\end{tabular}

Selain pengamatan keterampilan proses sains siswa, untuk mengukur keterampilan proses sains siswa menggunakan penilaian tes keterampilan proses sains, keterampilan proses yang diukur antara lain meliputi keterampilan memprediksi, merumuskan masalah, membuat hipotesis, menganalisa, mengidentifikasi variabel dan menyimpulkan. Hasil tes keterampilan proses siswa kelas eksperimen (VIII-E) disajikan pada Tabel 4.3.

Tabel 4.3 Nilai Keterampilan Proses Sains Kelas Eksperimen

\begin{tabular}{|l|l|c|}
\hline No & \multicolumn{1}{|c|}{ Kategori } & Jumlah Siswa \\
\hline 1 & Tinggi & 21 \\
\hline 2 & Sedang & 14 \\
\hline 3 & Rendah & - \\
\hline
\end{tabular}

Berdasarkan Tabel 4.3 diperoleh hasil perhitungan menggunakan Gain Score untuk tiap siswa dengan kategori yang dikemukakan oleh Hake (1999:1) diperoleh dari 35 jumlah siswa kelas eksperimen (VIII-E) didapatkan 21 siswa memperoleh nilai perhitungan $0,70<\mathrm{g}<1,00$, dengan demikian kategori peningkatan keterampilan prosesnya tinggi dan 14 siswa memperoleh nilai $0,30<\mathrm{g} \leq 0,70$ dengan kategori sedang. Secara umum pada kelas eksperimen peningkatan keterampilan proses sains sebesar 0,73 dengan kategori tinggi. Untuk ketuntasan individu sebanyak 23 siswa telah tuntas secara individu dan 12 siswa lain tidak tuntas. Siswa dinyatakan tidak tuntas secara individu karena nilai yang mereka peroleh dibawah KKM (Kriteria Ketuntasan Minimal) yang telah ditentukan sekolah, yakni $\geq 75$. Sedangkan untuk ketuntasan klasikal keterampilan proses sains siswa kelas eksperimen (VIIIE) belum tercapai dengan presentase $66 \%$. Untuk peningkatan keterampilan proses sains terkait dengan indikator keterampilan proses sains yang terdapat pada soal yang telah di ujikan disajikan pada Tabel 4.4.

Tabel 4.4 Peningkatan Keterampilan Proses Sains Kelas Eksperimen

\begin{tabular}{|l|c|c|c|}
\hline Keterampilan & $\begin{array}{c}\text { Nilai kelas } \\
\text { Eksperimen }\end{array}$ & Gain & Kriteria \\
\hline
\end{tabular}




\begin{tabular}{|c|c|c|c|c|}
\hline proses sains & $\begin{array}{c}\text { Pre- } \\
\text { test }\end{array}$ & $\begin{array}{c}\text { Post- } \\
\text { test }\end{array}$ & Score & \\
\hline K1 & 18 & 74 & 0,69 & Sedang \\
\hline K2 & 13 & 71 & 0,67 & Sedang \\
\hline K3 & 11 & 86 & 0,84 & Tinggi \\
\hline K4 & 5 & 96 & 0,95 & Tinggi \\
\hline K5 & 9 & 71 & 0,68 & Sedang \\
\hline K6 & 17 & 70 & 0,64 & Sedang \\
\hline
\end{tabular}

*Keterangan :

$\mathrm{K} 1=$ Memprediksi

K2 = Merumuskan Masalah

K3 = Merumuskan Hipotesis

K4 = Mengidentifikasi Variabel

K5 = Menganalisa

K6 = Menyimpulkan

Sedangkan nilai keterampilan proses sains pada kelas kontrol disajikan pada tabel 4.5

Tabel 4.5

Niai Keterampilan Proses Sains Kelas Kontrol

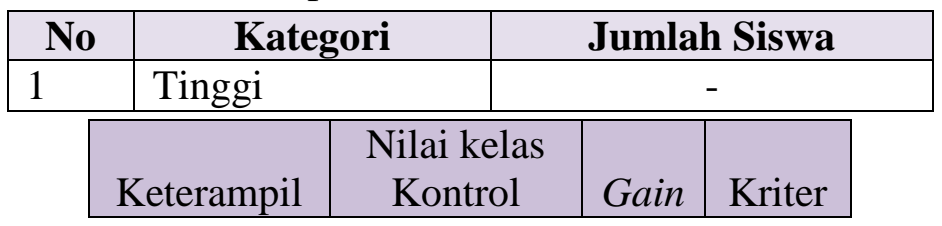

\begin{tabular}{|l|l|l|}
\hline 2 & Sedang & 22 \\
\hline 3 & Rendah & 13 \\
\hline
\end{tabular}

Berdasarkan Tabel 4.5 peningkatan keterampilan proses sains pada kelas kontrol dengan menggunakan analisis Gain Score yang telah dikemukakan oleh Hake (1991: 1). Secara umum pada kelas kontrol peningkatan keterampilan proses sains sebesar 0,36 dengan kategori sedang. Untuk ketuntasan individu sebanyak 35 siswa tidak tuntas secara individu. Siswa dinyatakan tidak tuntas secara individu karena nilai yang mereka peroleh dibawah KKM (Kriteria Ketuntasan Minimal) yang telah ditentukan sekolah, yakni $\geq 75$. Sedangkan untuk ketuntasan klasikal keterampilan proses sains siswa kelas eksperimen (VIII-E) belum tercapai dengan presentase $0 \%$.

Untuk peningkatan keterampilan proses sains terkait dengan indikator keterampilan proses sains yang terdapat pada soal yang telah di ujikan disajikan pada tabel 4.6.

Tabel 4.6

Peningkatan Keterampilan Proses Sains Kelas Kontrol 
*Keterangan :

$\mathrm{K} 1$ = Memprediksi

$\mathrm{K} 2=$ Merumuskan

$\mathrm{K} 3=$ Merumuskan

\begin{tabular}{|c|c|c|c|c|}
\hline & $\begin{array}{c}\text { Pre- } \\
\text { test }\end{array}$ & $\begin{array}{c}\text { Post- } \\
\text { test }\end{array}$ & & \\
\hline K1 & 19 & 29 & 0,11 & $\begin{array}{c}\text { Renda } \\
\mathrm{h}\end{array}$ \\
\hline K2 & 13 & 46 & 0,38 & $\begin{array}{c}\text { Sedan } \\
\mathrm{g}\end{array}$ \\
\hline $\mathrm{K} 3$ & 14 & 41 & 0,31 & $\begin{array}{c}\text { Sedan } \\
\mathrm{g}\end{array}$ \\
\hline $\mathrm{K} 4$ & 4 & 55 & 0,53 & $\begin{array}{c}\text { Sedan } \\
\mathrm{g}\end{array}$ \\
\hline $\mathrm{K} 5$ & 9 & 46 & 0,41 & $\begin{array}{c}\text { Sedan } \\
\mathrm{g}\end{array}$ \\
\hline $\mathrm{K} 6$ & 15 & 48 & 0,39 & $\begin{array}{c}\text { Sedan } \\
\mathrm{g}\end{array}$ \\
\hline
\end{tabular}

Masalah

Hipotesis

K4 = Mengidentifikasi Variabel

K5 = Menganalisa

K6 = Menyimpulkan

Berdasarkan Tabel 4.6 peningkatan paling tinggi yaitu keterampilan mengidentifikasi variabel sebesar 0,53 dan keterampilan proses sains paling rendah adalah keterampilan memprediksi sebesar 0,11. Adapun perbedaan peningkatan keterampilan proses sains antara kelas eksperimen dan kelas kontrol disajikan pada Grafik 4.1.

Grafik 4.1 Peningkatan Keterampilan Proses Sains

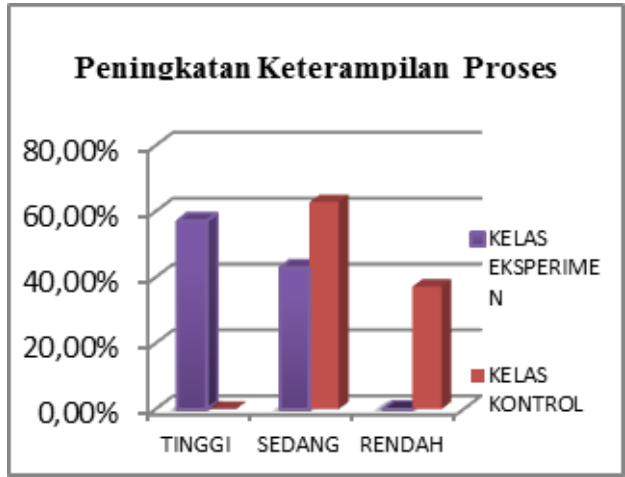

Berdasarkan Grafik 4.1 peningkatan keterampilan proses sains siswa kelas eksperimen lebih baik dari pada kelas kontrol. Adapun rata-rata peningkatan hasil keterampilan proses sains siswa tiap aspek disajikan dalam Grafik 4.2.

Grafik 4.2 Peningkatan Keterampilan Proses Sains Tiap Aspek 


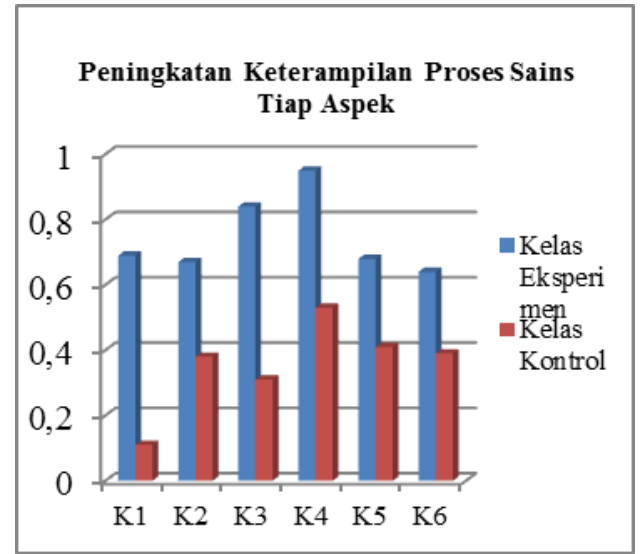

Berdasarkan Grafik 4.2 peningkatan keterampilan proses sains tiap aspek pada kelas eksperimen lebih baik dari pada kelas kontrol.

\section{Analisis Angket Respon Siswa}

Analisis respon siswa pada kelas eksperimen dengan model pembelajaran $7 E$ dalam IPA Terpadu tema Energi Biomassa dikategorikan sangat baik yang digambarkan dalam Grafik 4.6.

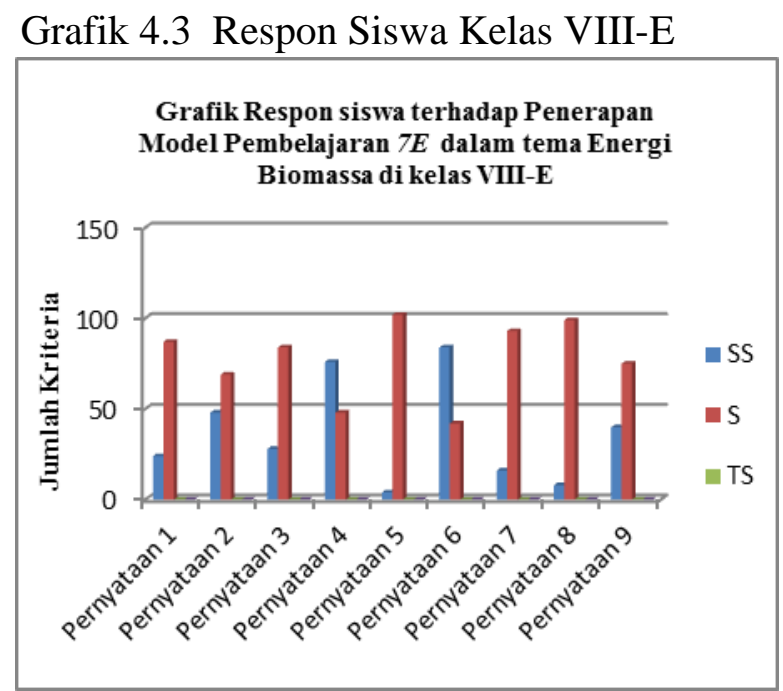

Berdasarkan Grafik 4.3 Respon siswa paling positif pada pernyataan bahwa melalui model pembelajaran $7 E$ dalam tema Energi Biomassa dapat memperluas wawasan ilmu pengetahuan yang sebelumnya belum mereka ketahui. Sedangkan respon paling sedikit mereka dapat menjelaskan konsep-konsep materi dalam tema Energi Biomassa dari kegiatan demonstrasi yang mereka lakukan di kelas.

\section{Pembahasan}

Berdasarkan analisis data hasil penelitian yang dilakukan menunjukkan keterlaksanaan pembelajaran dengan menggunakan model pembelajaran $7 E$ dapat terlaksana semua dengan baik dengan skor rata-rata 3,6 dan tingkat reliabilitas 0,86 .

Proses pembelajaran yang dilakukan oleh guru peneliti yang paling tinggi adalah aspek persiapan. Guru peneliti memiliki persiapan dan perancangan pembelajaran sangat baik terutama dalam menyiapkan perangkat pembelajaran dan media pembelajaran. Perancangan 
pembelajaran yang baik merupakan salah satu kompetensi yang harus dimiliki oleh seorang guru karena dapat berpengaruh terhadap proses pembelajaran. Hal ini sesuai dengan pendapat Mulyasa (2007:75), bahwa guru harus memiliki kemampuan dalam pegelolaan pembelajaran peserta didik yang salah satunya adalah perancangan pembelajaran.

Pada pembelajaran di kelas Eksperimen guru peneliti melatihkan keterampilan proses sains kepada siswa disetiap fase dengan menggunakan model pembelajaran 7E. Karena proses pembelajaran akan berdampak pada keterampilan proses sains dan hasil belajar. Hal ini sesuai dengan pendapat Mulyasa (2009: 5) bahwa guru memegang peran utama dalam pembangunan pendidikan agar terciptanya proses dan hasil pendidikan yang berkualitas dan penentu keberhasilan peserta didik.

Proses pembelajaran di kelas Eksperimen dan kelas Kontrol diawali dengan pemberian motivasi. Karena motivasi merupakan salah satu komponen terpenting dalam pembelajaran (Slavin, 2009 : 105). Skor pengamatan pemberian motivasi pada guru peneliti sangat baik. Siswa yang termotivasi untuk mempelajari sesuatu menggunakan proses kognitif yang lebih tinggi mempelajarinya dan menyerap lebih banyak mempelajari, menyerap dan mengingat (Slavin, 2009: 106). Sehingga keterampilan proses sins dan hasil belajar akan mengalami peningkatan.

Sedangkan skor paling rendah terdapat pada keterlaksanaan suasna kelas yang baik. Sulitnya guru dalam mengkondisikan kelas. Hal ini selaras dengan kelemahan penggunaan model pembelajaran $7 E$. Efektifitas pembelajaran rendah rendah jika guru kurang menguasai materi dan langkah-langkah pembelajaran (Deny, 2009 :25).

Selanjutnya dari analisis keterampilan proses sains siswa antara kelas eksperimen dan kelas kontrol mengalami peningkatan. Perhitungan analisis Gain Score menunjukkan peningkatan 0,73 dan secara umum rata-rata peningkatan keterampilan proses sains kelas eksperimen tinggi. Sedangkan pada kelas kontrol meningkat sebesar 0,36 dan secara umum rata-rata mengalami peningkatan keterampilan proses sains sedang.Pada kedua kelas peningkatan keterampilan proses sains paling signifikan pada aspek mengidentifikasi variabel. Identifikasi variabel merupakan keterampilan proses sains dengan ranah analisis sehingga kemampuan mengidentifikasi variabel masih dapat dilatihkan dengan mudah. Tetapi pada dasarnya kedua kelas telah mengalami peningkatan. Peningkatan dapat disebabkan karena kedua kelas menggunakan kegiatan percobaan dalam proses pembelajaran dan media pembantu yang berupa LKS (Lembar Kerja Siswa). Sehingga kemampuan keterampilan proses sains kedua kelas dapat meningkat dengan kriteria belum mencapai ketuntasan secara klasikal. Hal ini telah menunjukkan bahwa keterampilan proses sains tidak dapat dilatihkan dalam beberapa waktu saja. Tetapi harus dilatihkan dalam proses pembelajaran setiap waktu. Selain itu juga kurang aktifnya siswa dalam melakukan diskusi kelompok yang terlihat pada skor rata-rata keterlaksanaan pembelajaran rendah pada tahap explorasi dan explain sehingga berdampak pada keterampilan proses sains siswa. Siswa juga belum terlatih untuk melakukan pengamatan. Hal ini dibuktikan nilai pengamatan kelas Eksperimen maupun kelas Kontrol rendah.

Peningkatan secara signifikan dapat terlihat pada kelas eksperimen, hal ini dikarenakan pada kelas eksperimen menerapkan model pembelajaran $7 E$ yang dapat melatihkan keterampilan proses sains pada siswa secara spesifik dalam tahapan-tahapan tertentu dengan berpendekatan kontruktivis. Melalui pembelajaran konstruktivisme siswa belajar secara aktif 
dan dapat mengaitkan informasi yang baru dengan skema yang telah dimiliki sebelumnya. Melalui pembelajaran kontruktivis, pengetahuan yang dimiliki siswa sangat bermakna, relevan dan memberikan kesempatan bagi siswa bagaimana cara siswa bertindak serta berfikir (Slavin, 2009: 6).

Hal ini mendukung pernyataan bahwa siklus belajar atau Learning Cycle merupakan model pembelajaran yang berorientasi pada model pembelajaran kontruktivis (Carin, 1993: 87).

Hal ini selaras dengan penelitian yang dilakukan oleh Lisna (2013) menyatakan bahwa keterampilan proses sains siswa mengalami peningkatan setelah diajarkan dengan model pembelajaran $7 E$. Dapat disimpulkan bahwa model pembelajaran $7 E$ dapat meningkatkan keterampilan proses sains siswa yang telah diuji menggunakan uji t.

Secara umum kriteria persentase angket respon siswa pada kelas eksperimen adalah sangat baik sebesar $82 \%$ bahwa siswa memperoleh pengetahuan baru yang belum mereka ketahui sebelumnya. Hal ini sesuai dengan pemilihan tema dalam pembelajaran IPA Terpadu. Dalam menentukan tema, perlu memperhatikan beberapa hal, yaitu: relevansi tema dengan kompetensi dasar yang dipadukan, tema yang dipilih merupakan isu-isu yang aktual, menarik, dan kontekstual (Depdiknas, 2006: 19).

Berdasarkan hasil analisis angket respon dapat diketahui bahwa penerapan model pembelajaran $7 E$ mendapat respon yang positif dari siswa. Karena siswa sangat berperan aktif dalam proses pembelajaran sehingga pembelajaran pada akhirnya menyenangkan. Hal ini sesuai dengan pernyataan bahwa model pembelajaran $7 E$ merupakan model pembelajaran konstruktivis yang berpusat pada siswa (Eisenkraft, 2003: 57).

\section{PENUTUP}

\section{Simpulan}

Berdasarkan hasil penelitian yang telah dilakukan diperoleh simpulan sebagai berikut: 1)Kegiatan pembelajaran dengan menggunakan model pembelajaran $7 E$ dalam IPA Terpadu tema Energi Biomassa terlaksana sangat baik dengan rata-rata skor 3,6. 2)Pembelajaran dengan menggunakan model pembelajaran $7 E$ dalam IPA Terpadu tema Energi Biomassa dapat meningkatkan keterampilan proses sains sebesar 0,73 dengan peningkatan tinggi. 3)Pembelajaran dengan menggunakan model pembelajaran $7 E$ dalam IPA Terpadu tema Energi Biomassa mendapat respon positif dari siswa sebesar $82 \%$ dengan kategori sangat baik. Karena dalam model pembelajaran $7 E$ merupakan pembelajaran aktif. Sehingga siswa berperan penting dalam proses pembelajaran.

\section{Saran}

Berdasarkan hasil penelitian yang telah dilakukan, maka peneliti memberikan beberapa saran agar penelitian berikutnya berjalan lancar dan lebih baik yaitu: 1)Pengelolaan waktu pembelajaran yang dilakukan harus maksimal, karena masih banyak siswa yang kurang memahami tentang percobaan yang akan dilakukan dan peneliti harus menjelaskan satu persatu sehingga membutuhkan waktu yang lebih lama, 2)Belum terbiasa dengan kegiatan pembelajaran menggunakan model pembelajan $7 E$ dalam pembelajaran IPA Terpadu tema Energi Biomassa. Sehingga terdapat beberapa siswa yang cenderung pasif dalam kegiatan diskusi dan percobaan, 3) Keterampilan proses sains tidak dapat dilatihkan dalam beberapa 
waktu saja, tetapi harus dilatihkan dalam proses pembelajaran setiap waktu. 4) Untuk penelitian selanjutnya, diharapkan menerapkan model pembelajaran $7 E$ pada tema lain, karena model pembelajaran $7 E$ dapat melatihkan keterampilan proses sains pada siswa.

\section{DAFTAR PUSTAKA}

Aditya, R. 2012. Implementasi Model Pembelajaran Leaning Cycle $7 E$ Sebagai Upaya Meningkatkan Prestasi Belajar Siswa. Skripsi Sarjana UNY Jogyakarta: tidak diterbitkan.

Carin, A. 1993. Teaching Science Though Discovery. Seventh Edition. New York: Memillan Publising Company.

Departemen Pendidikan Nasional. 2006. Panduan Pengembangan Pembelajaran IPA Terpadu. Jakarta: Puskur, Balitbang Depdiknas.

Deny. 2009. Penerapan Model Pembelajaran Learning Cycle $7 E$ Untuk Meningkatkan Keterampilan Berfikir Kristis Dan Penguasaan Konsep SMA".Skripsi Sarjana pada FPMIPA UPI Bandung: tidak diterbitkan.

Eisenkraft, A. 2003. Expanding the 5E model.A proposed 7E model emphasizes "transfer of learning” 56-59. [online]. Tesedia:http://its-about-timr.com/htmls/ap/eisenkraft.pdf. [ Diakses 10 Februari 2013].

Fogarty, R. 1991. How ToIntegrateTheCurricula. Illionis , IRI/Skylight Publishing, Inc

Hake . Analyzing Change/Gain Scores. [Online]. Tersedia : <http://lists.asu.edu/cgi bin/wa?A2=ind9903\&L=aera-d\&P=R6855>).

Ibrahim, M. 2010. Dasar-Dasar Proses Belajar Mengajar. Surabaya : Unipress.

Institut Pertanian Bogor. BAB III. ENERGI BIOMASSA. [online]. Tersedia : http://web.ipb.ac.id/ tepfteta/elearning/media/Energi\%20dan\%20Listrik\%20Pertani an/MATERI\%20WEB\%20ELP/Bab\%20III\%20BIOMASSA/indexBIOMASSA.htm . [Diakses 10 April 2013].

Lisna, H. 2013. Meningkatkan Keterampilan Proses Sains Siswa Pada Mata Pelajaran IPA Materi Gaya Melalui Penerapan Model Pembelajaran Learning Cycle $7 E$. Skripsi Sarjana UPI Bandung: tidak diterbitkan.

Mulyasa, E. 2009. Standar Kompetensi dan Sertifikasi Guru. Bandung: PT Remaja Rosdakarya.

Nana, S. 2010. Metode Penelitian Pendidikan. Bandung : PT Remaja Rosdakarya.

Nur, M. 2008. Pengajaran Berpusat Pada Siswa dan Pendekatan Kontruktivis dalam Pengajaran. Surabaya: Unipress.

Riduwan. 2010. Skala Pengukuran Variabel-Variabel Penelitian. Bandung: Alfa Beta.

Slavin, R. 2009. Psikologi Pendidikan. Jakarta: PT. Indeks.

Sudjana. 2005. Metoda Statistika. Bandung: Tarsito.

Trianto. 2007. Model Pembelejaran Terpadu Dalam Teori Dan Praktek. Jakarta: Prestasi Pustaka. 